\title{
CAN HIGH DIVIDEND YIELD SUSTAIN FIRM VALUE DURING THE COVID-19 CRASH? EVIDENCE FROM TURKISH FIRMS
}

\author{
Res. Asst. Ömer Faruk TAN (Ph.D.) * \\ Res. Asst. Hakan CAVLAK (Ph.D.) * \\ Res. Asst. Yasin CEBECI (Ph.D.) * \\ Res. Asst. Necati GÜNEŞ * iD
}

\begin{abstract}
In this study, we want to investigate whether having a high dividend yield has a catalyst effect on stock prices during the COVID-19 turmoil period. 164 manufacturing firms in Borsa Istanbul are classified as firms with high and low dividend yield according to their last five-years' (2015-2019) averages. The analysis results show that the stock returns of firms with high dividend yield are less impacted in this COVID-19 crash. Likewise, firms with a high frequency of dividend payouts are less affected than those who do not. This study reveals that firms with high dividend yield are regarded as safe havens by investors in this crash caused by COVID-19.
\end{abstract}

Keywords: COVID-19, Dividend Yield, Borsa Istanbul, Firm Value, Daily Cases, Daily Deaths.

JEL Codes: G12, G32, G35

\section{YÜKSEK TEMETTÜ GETIRISİ COVID-19 ÇÖKÜŞÜ SIRASINDA FİRMA DEĞERINİ KORUYABİLIR MI?? TÜRK FİRMALARINDAN KANITLAR}

\section{ÖZET}

Bu çalışmada, yüksek temettü getirisine sahip olmanın, COVID-19 kargaşası döneminde hisse senedi fiyatları üzerinde katalizör etkisi olup olmadığı araştırılmıştır. Borsa İstanbul'daki 164 imalatçı firma, son beş yıllık (2015-2019) ortalamalarına göre temettü getirisi yüksek ve düşük olan firmalar olarak sınıflandırılmıştır. Analiz sonuçları, yüksek temettü getirisi olan firmaların hisse senedi getirilerinin COVID-19 çöküşünden daha az etkilendiğini göstermektedir. Aynı şekilde, temettü ödemesi sıklı̆̆ yüksek olan firmalar, yapmayanlara göre daha az etkilenmektedir. Bu çalışma, yüksek temettü

\footnotetext{
* Marmara University, Faculty of Business Administration, Istanbul/ Türkiye. E-mail: omer.tan@ marmara.edu.tr

* Ardahan University, F.E.A.S., Ardahan/ Türkiye. E-mail: hakancavlak@ardahan.edu.tr

* Marmara University, Faculty of Business Administration, Istanbul/ Türkiye. E-mail: yasin.cebeci@ marmara.edu.tr

* Marmara University, Faculty of Business Administration, Istanbul/ Türkiye. E-mail: necati.gunes@ marmara.edu.tr
}

\section{Makale Gecmisi/Article History}


getirisi olan firmaların, COVID-19'un neden olduğu bu çöküşte yatırımcllar tarafindan güvenli liman olarak görüldüğ̈̈nü ortaya koymaktadır.

Anahtar Kelimeler: COVID-19, Temettü Getirisi, Borsa İstanbul, Firma Değeri, Günlük Vakalar, Günlük Ölümler.

JEL Kodları: $G 12, G 32, G 35$

\section{INTRODUCTION}

COVID-19 was first detected in Wuhan, People's Republic of China, in early January 2020. It quickly spreads around the world affecting many areas such as domestic demand, tourism and business travels, trade and production links, supply and supply chains. Uncertainty and risk caused by COVID19 led to characterizing the pandemic as a unique situation (Abiad et al., 2020; Brodeur et al., 2020; OECD, 2020; Sharma et al., 2020).

The global health crisis COVID-19, which sparked the worst global recession since the Second World War, dramatically restricted economic activity through various channels, triggering significant impacts on the global economy and massive structural changes (Haruhiko, 2020; World Bank, 2021; Wu \& Olson, 2020). Global health disasters have health impacts and cause far-reaching socio-economic disruption and losses (Ahmad et al., 2020). COVID-19 caused a public health crisis and a global economic and social problem; it brought the world economy to a halt. It has had serious negative effects on employees, customers, supply chains and financial markets, and has led to permanent policy changes in health, diplomacy, security, production, trade, employment, agriculture and science. According to the OECD, the pandemic is one of the most significant public health and economic crises that occur simultaneously in modern times. In addition, it has impacts that will be felt not only in 2020 but for decades to come (Açıkgöz \& Günay, 2020; Amankwah-Amoah, Khan, \& Wood, 2020; Landry, 2020).

COVID-19 has taken advantage of the weaknesses of globalization as it evolved from a regional crisis to a global pandemic, causing great uncertainty in all countries, large or small, developed or emerging. In other words, it led to severe recessions in many countries, creating a massive shock of uncertainty in the global economy. The crisis atmosphere created by the pandemic in the economy differs from the previous economic crises. The most important reason for this is that the pandemic has a similar environment to the uncertainty that occurs in wars and political crises (Baker et al., 2020; Barua, 2020; Gans, 2020; IMF, 2020; United Nations, 2020; World Bank, 2021). COVID-19 has caused financial markets and supply chain disruptions, market volatility, production delays-limitationsinterruptions, decrease in demand (from both commercial customers and consumers), sales, earnings or productivity, closure of facilities and stores, loss of customers and troubles in important contracts. In addition, sharp declines and fluctuations occurred in the stock markets and commodity prices consumers have to stay at home after increasing unemployment levels, businesses losing their income, and firing workers caused a decrease in investment contracts, an increase in corporate bankruptcies, and thus a 
significant pressure on the financial system (Baker et al., 2020; McKibbin \& Fernando, 2020; McKinsey \& Company, 2020).

Governments also introduced several preventive measures to mitigate the impact of the pandemic, such as export prohibitions, import tariffs, travel restrictions and stimulus packages (providing support to workers and businesses). It has become imperative to understand what impact these policies have on firms, economies and markets to create future projections (Assche \& Lundan, 2020; Narayan, Phan, \& Liu, 2020).

Although it is clear that COVID-19 causes economic disruption at an unprecedented pace and scale, the true extent of its economic impact is still not fully known (Baldwin \& Mauro, 2020; Chen et al., 2020). Despite this obscurity, academic studies continue to investigate the effect of the pandemic on both the economy and businesses. One of the research areas, which is addressed in this study, is whether high dividend yield in this turmoil period acts as a catalyst on the stock performance of firms. In business finance, there are three important decisions to maximize firm value. Decisions about where to invest the funds collected by the firm internally or externally (investment decision), decisions about where and how to raise funds to finance these investments (financing decision) and how much and in what form the funds are returned to their owners (dividend decision). As can be seen, the dividend decision is closely linked to both investment and financing decisions and cannot be evaluated separately from each other. Therefore, dividend policies constitute one of the three most important decision-making areas in corporate finance (Bradley, Capozza, \& Seguin, 1998; Damodaran, 2015; Forti, Peixoto, \& Alves, 2015; Pruitt \& Gitman, 1991; Watson \& Head, 2016).

The effects of dividend payment on firm value (increases or decreases, whether it can be used to change the market's firm value perception), firm performance (positive or negative), shareholder wealth (whether maximizes or not) are the focus of many studies (Adjaoud \& Ben-Amar, 2010; Laux, 2011; Marseguerra, 1998; Panigrahi \& Zainuddin, 2015). Finance experts have developed extensive theories to explain why firms will or should not pay dividends. Researchers have developed and experimentally tested various models to explain dividend behavior. Some of them surveyed company executives and institutional investors to determine their views on dividends. Despite extensive debates and researches, dividend policy remains one of the most controversial issues in finance (Asquith \& Mullins, 1983; Baker \& Powell, 1999; Ross, Westerfield, \& Jordan, 2017).

The payment of dividends is one of the factors that determine both shareholders' wealth and the firm's ability to retain earnings to take advantage of growth opportunities (Baker, 2009). Therefore, the dividend payment has significant effects as it satisfies existing shareholders and persuades new ones (Ranajee, Pathak, \& Saxena, 2018). Some of these effects are the reflections of the dividend policies, which firms steer according to the dividend return demands of investors (Black \& Scholes, 1974), on firm performance, profitability or investment opportunities (Dewasiri et al., 2019; Kanakriyah, 2020). 
One of the research questions that are sought to be answered in the studies is whether the payment of dividends (dividend yield) affects the performance of firms (Denis \& Osobov, 2008). Findings show that the increase (decrease) in dividend payment affects firms' market value or the dividend policy of firms does not affect their value (Ahmed \& Javid, 2008; Holder, Langrehr, \& Hexter, 1998). Within the above-mentioned framework, 164 manufacturing firms in Borsa Istanbul are categorized as firms with high and low dividend yield according to their last five-years' (2015-2019) averages. Our aim in this study is to analyze whether having a high dividend yield has a protective effect on stock prices during the COVID-19 crash. To the best of our knowledge, our study is the first one on this topic, and we want to fill the gap in the literature.

\section{LITERATURE REVIEW AND HYPOTHESIS}

Many issues that are thought to be affected by COVID-19 have been examined in the literature, such as the impact on stock market returns and volatility (Al-Awadhi et al., 2020; Albulescu, 2020; Ali, Alam, \& Rizvi, 2020; Ashraf, 2020b, 2020c; Bahrini \& Filfilan, 2020; Chaudhary, Bakhshi, \& Gupta, 2020; Harjoto et al., 2020; Kartal, Depren, \& K1lıç-Depren, 2020; Kartal, K1lıç-Depren, \& Depren, 2020; Mazur, Dang, \& Vega, 2020; Rababah et al., 2020; Sergi et al., 2021; Thorbecke, 2020; Topcu \& Gulal, 2020), trade volume (Chiah \& Zhong, 2020; Harjoto et al., 2020), government responses or interventions (Ashraf, 2020a; Chen et al., 2020; Zaremba et al., 2021; Zaremba et al., 2020), oil prices (Corbet, Goodell, \& Günay, 2020; Devpura \& Narayan, 2020; Fu \& Shen, 2020; Huang \& Zheng, 2020; Prabheesh, Padhan, \& Garg, 2020; Salisu, Ebuh, \& Usman, 2020), tourism and leisure sectors (Demir et al., 2020; Ghosh, 2020; Kaczmarek et al., 2021), herd behavior (Chang, McAleer, \& Wang, 2020; Espinosa-Méndez \& Arias, 2020), cryptocurrencies (Conlon \& McGee, 2020; Corbet, Larkin, \& Lucey, 2020; Demir et al., 2020; Goodell \& Goutte, 2020), gold prices (Corbet et al., 2020), bond yields (Fendel, Neugebauer, \& Zimmermann, 2021), green bond market (Yi et al., 2021), contagion effect (Okorie \& Lin, 2020), brand equity (Huang, Yang, \& Zhu, 2021), market illiquidity (Baig et al., 2020; Farzami et al., 2021), mutual funds (Mirza et al., 2020; Yarovaya et al., 2021), uncertainty (Jeris \& Nath, 2020; Szczygielski et al., 2021), housing prices (Qian, Qiu, \& Zhang, 2021) and industrial reactions (Chen \& Yeh, 2021).

The only study we know of analyzing the effect of COVID-19 on dividend payment is the following paper. Krieger \& Mauck (2020) examine the impact of the pandemic on dividend payments of publicly traded firms in the US. Accordingly, out of the 1.400 dividend-paying firms, 213 cut dividends, while 93 of them do not pay any dividends. They find that this decline in dividends was three to five times higher than in all other quarters since 2015.

Studies analyzing the relationship between dividend yield and firm performance are available in the literature. Murekefu \& Ouma (2012) searched the relationship between dividend payment and firm performance according to the data of 41 firms traded on the Nairobi Stock Exchange for 2002 and 2010. 
They found that the dividend payment is an important factor affecting firm performance positively. M'rabet \& Boujjat (2016) analyzed the relationship between dividend policies and financial performance using the 2010-2014 data of 44 firms traded in Casablanca Stock Exchange (CSE) in Morocco. It has been demonstrated that the dividend policy is an important factor affecting firm performance. Farrukh et al., (2017) investigated the impact of dividend policy on shareholders' wealth and firm performance. The data of the 51 companies, listed on the Pakistani Stock Exchange and paying dividends for ten consecutive years or pursuing stable dividend policies with intervals of one or two years at most, are used for the period 2006-2015. They determined that the dividend policy has a significant positive impact on shareholders' wealth and firm performance. Kanakriyah (2020) surveyed the relationship between the dividend policy and the financial performance of companies in developing countries. The data of 92 industrial and service sector companies listed on the Amman Stock Exchange (ASE) for the period 2015-2019 are used. They inferred that the dividend policy has a statistically significant impact on the financial performance of the companies. Therefore, we propose the following hypothesis:

Hypothesis: Firms with high dividend yield perform better in the COVID-19 crash.

\section{DATA AND METHODOLOGY}

In this research, we explore whether, during COVID 19 turmoil period, having a high dividend yield could act as a catalyst for stock prices. For this analysis, data of 164 manufacturing firms in Borsa Istanbul are used in the study. The study period is chosen between 10 March 2020 and 17 April 2020. The reason for selecting March 10 as start day is the date of the first COVID-19 case announced in Turkey and to choose the last day as April 17 is that while the uncertainty continued as of mid-April, the stock markets begin to recover to a certain extent (Cepoi, 2020), and studies in the literature considered April 17 as the last day (Ashraf, 2020a, 2020b, 2020c; Baig et al., 2020; Cepoi, 2020). Our final data consists of 4.592 observations after excluding weekend holidays.

Firstly, firms are ranked with respect to their average dividend yield over the last five years (20152019). The median is then calculated, and the firms are categorized as below and above median according to their average dividend yield. For the robustness check, we also generate alternative classification criteria. (in Table 1). First of all, we exclude firms that do not pay dividends and calculate the median again. While the median is 0.45 in the previous one, it is 2.85 according to this new criterion, and we categorize firms based on the new median. Secondly, if firms pay dividends at least once in the last five years, they are known as "dividend payers" otherwise "non-dividend payers". Finally, firms are classified by their dividend distribution frequency into three groups. Firms in the first group are categorized as the ones that do not pay dividends or pay one time. In the second group, firms pay dividends two or three times, and in the third group, firms pay dividends four or five times in the last five-year period. Dividend yield data are obtained from https://temettuhisseleri.com, 
https://www.isyatirim.com.tr and https://tr.investing.com. The daily stock prices are taken from Thomson Reuters DataStream, and the daily stock returns are calculated for each firm. The number of cases and deaths in Turkey is used as a variable to analyze the effects of coronavirus on stock prices. These data are acquired from https://ourworldindata.org/. We measure cases and deaths as the daily new cases divided by the cumulative cases and the daily new deaths divided by the cumulative deaths (Harjoto et al., 2020). Furthermore, we add the stringency index and infodemic index as a variable. The stringency index is provided by the Oxford COVID-19 Government Response Tracker database (Hale et al., 2020) and gives information on social distancing measures. We want to capture the influences of government interventions on stock prices. We also add an infodemic index that is provided by the Ravenpack Data Platform. This data analytics platform provides the latest info about coronavirus and measures panic, sentiment and misinformation. The infodemic index measures the percentage of all entities (places, companies, etc.) connected to COVID-19 in somehow. A detailed description of each variable is given in the Appendix.

Table 1. Classification Criteria

\section{Criterion 1}

Median1: Categorizing firms as above and below median according to their dividend yield average in the last five years (2015-2019)

\section{Criterion 2}

Median2: Categorizing firms as above and below median according to their dividend yield average in the last five years (2015-2019) - Excluding non-dividend payers

\section{Criterion 3}

If a firm pays a dividend at least once, it is included in the "dividend payers" group.

\section{Criterion 4}

Group 1: Firms pay dividends once or never in the last five years.

Group 2: Firms pay dividends two or three times in the last five years.

Group 3: Firms pay dividends four or five times in the last five years.

\section{EMPIRICAL FINDINGS AND DISCUSSIONS}

Descriptive statistics for variables and correlation matrix results are shown in the Appendix. In this period, the stock returns of firms with high dividend yield perform better than those with low dividend yield and lower standard deviation. According to the correlation matrix, there is a negative and significant relationship between the stock returns of firms with low dividend yield and the number of daily cases and deaths. On the other hand, the relationship is not significant for the above-median firms. The stringency index and infodemic index have negatively significant correlations with all firms.

Table 2 indicates the analysis results according to median1 and median2. First of all, the results reveal that the effect of daily deaths on stock prices is more than the number of daily cases. The one percent increase in the number of deaths causes the average four-five percent decrease in stock prices. 
Although the increase in the number of cases and deaths generally affects stock prices significantly and negatively, the value and the magnitude of the coefficients are lower for above-median firms. One percent increase in the daily new cases leads to declines of stock prices around two percent for firms with below-median, while it is around one percent for firms with above-median. Likewise, the one percent increase in the daily deaths causes a decline in stock prices around five percent for firms with below-median, whereas it is approximately three and a half percent for firms with below-median. Therefore, our results are consistent with our Hypothesis. Table 3 indicates the results for third and fourth criteria. The results are consistent with the previous ones, and the stock prices of the firms with high dividend payments are less affected. In general, we can say that firms with high dividend yield are less affected by the pandemic crash. In other words, investors believe in these firms more in this time. 
Yönetim ve Ekonomi Araștirmaları Dergisi / Journal of Management and Economics Research Cilt/Volume: 19 Sayl/Issue: 2 Haziran/June 2021 ss. /pp. 334-352

Ö. F. Tan, H. Cavlak, Y. Cebeci, N. Güneș Doi: http://dx.doi.org/10.11611/yead.915018

Table 2. Empirical Results for Criterion 1 and 2

\begin{tabular}{|c|c|c|c|c|c|c|c|c|}
\hline & \multicolumn{4}{|c|}{ Median1 } & \multicolumn{4}{|c|}{ Median2 } \\
\hline Variables & 1 & 2 & 1 & 2 & 1 & 2 & 1 & 2 \\
\hline Cases & $\begin{array}{c}-0.0193 * * * \\
(0.00413)\end{array}$ & & $\begin{array}{l}-0.00704 * \\
(0.00351)\end{array}$ & & $\begin{array}{c}-0.0211 * * * \\
(0.00458)\end{array}$ & & $\begin{array}{l}-0.0103 * * \\
(0.00418)\end{array}$ & \\
\hline Deaths & & $\begin{array}{c}-0.0580 * * * \\
(0.00411)\end{array}$ & & $\begin{array}{c}-0.0340 * * * \\
(0.00578)\end{array}$ & & $\begin{array}{c}-0.0607 * * * \\
(0.00486)\end{array}$ & & $\begin{array}{c}-0.0412 * * * \\
(0.00471)\end{array}$ \\
\hline Stringency Index & $\begin{array}{c}-0.00224 * * * \\
(0.00009)\end{array}$ & $\begin{array}{l}-0.00003 \\
(0.00044)\end{array}$ & $\begin{array}{c}-0.00246 * * * \\
(0.00008)\end{array}$ & $\begin{array}{l}-0.00075^{*} \\
(0.000413)\end{array}$ & $\begin{array}{c}-0.00223^{* * * *} \\
(0.000103)\end{array}$ & $\begin{array}{c}0.00007 \\
(0.00051)\end{array}$ & $\begin{array}{c}-0.00237 * * * \\
(0.00009)\end{array}$ & $\begin{array}{l}-0.00056 \\
(0.00043)\end{array}$ \\
\hline Infodemic Index & $\begin{array}{c}-0.00122 * * * \\
(0.00009)\end{array}$ & $\begin{array}{c}-0.000519 * * * \\
(0.00010)\end{array}$ & $\begin{array}{c}-0.00131 \text { *** } \\
(0.00008)\end{array}$ & $\begin{array}{c}-0.000816^{* * *} \\
(0.00009)\end{array}$ & $\begin{array}{c}-0.00115^{* * * *} \\
(0.00012)\end{array}$ & $\begin{array}{c}-0.00042 * * \\
(0.00013)\end{array}$ & $\begin{array}{c}-0.00133^{* * *} \\
(0.00007)\end{array}$ & $\begin{array}{c}-0.00078 * * * \\
(0.00008)\end{array}$ \\
\hline Constant & $\begin{array}{c}0.0421 * * * \\
(0.00103)\end{array}$ & $\begin{array}{c}0.0526 * * * \\
(0.00096)\end{array}$ & $\begin{array}{l}0.0113 * * * \\
(0.000874)\end{array}$ & $\begin{array}{c}0.0186 * * * \\
(0.00124)\end{array}$ & $\begin{array}{c}0.0185 * * * \\
(0.00116)\end{array}$ & $\begin{array}{c}0.0293 * * * \\
(0.00109)\end{array}$ & $\begin{array}{c}0.0477 * * * \\
(0.00103)\end{array}$ & $\begin{array}{c}0.0560 * * * \\
(0.00111)\end{array}$ \\
\hline Observations & 3.248 & 2.784 & 1.344 & 1.152 & 2.296 & 1.968 & 2.296 & 1.968 \\
\hline
\end{tabular}

Median1 categorizes firms as above and below median according to their dividend yield average in the last five years (2015-2019). Median2 classifies firms as above and below median according to their dividend yield average in the last five years (2015-2019) - Excluding non-dividend payers. Daily new cases are divided by the cumulative cases. Daily new deaths are divided by the cumulative deaths. The infodemic index calculates the percentage of all entities (places, companies, etc.) that are somehow linked to COVID-19. Value range between 0 and 100 where a value of 70.00 means that 70 percent of all entities covered by the media are being linked or co-mentioned with COVID-19. The stringency index is based on different government interventions and rescaled to create a score between 0 and 100 (strict=100). The index covers eight policy indicators, school closing, workplace closing, cancellation of public events, restrictions on gathering size, closing public transport, staying at home requirements, restrictions on internal movement, and international travel restrictions. Robust standard errors in parentheses. $* * * \mathrm{p}<0.01, * * \mathrm{p}<0.05, * \mathrm{p}<0.1$

The stringency index has a negative effect on stock prices. The government's social distance measures to prevent the spread of the disease have a negative impact on the stocks. A decrease in both consumption and production due to social distance rules negatively affects the markets (Ashraf, 2020a, 2020b, 2020c; Chen et al., 2020). The infodemic index has a negative effect on stock prices for all firms. As entities related to COVID-19 news emerges, it creates panic among investors and adversely affects stock prices (Cepoi, 2020; Haroon \& Rizvi, 2020). 
Cilt/Volume: 19 Sayl/Issue: 2 Haziran/June 2021 ss. /pp. 334-352

Ö. F. Tan, H. Cavlak, Y. Cebeci, N. Güneș Doi: http://dx.doi.org/10.11611/yead.915018

Table 3. Empirical Results for Criterion 3 and 4

\begin{tabular}{|c|c|c|c|c|c|c|c|c|c|c|}
\hline \multirow[b]{2}{*}{ Variables } & \multicolumn{2}{|c|}{ Non-Dividend Payers } & \multicolumn{2}{|c|}{ Dividend Payers } & \multicolumn{2}{|c|}{ Group 1} & \multicolumn{2}{|c|}{ Group 2} & \multicolumn{2}{|c|}{ Group 3} \\
\hline & 1 & 2 & 1 & 2 & 1 & 2 & 1 & 2 & 1 & 2 \\
\hline Cases & $\begin{array}{c}-0.0223 * * * \\
(0.00470)\end{array}$ & & $\begin{array}{c}-0.00959 * * \\
(0.00406)\end{array}$ & & $\begin{array}{c}-0.0208^{* * *} \\
(0.00440)\end{array}$ & & $\begin{array}{c}-0.0189^{* *} \\
(0.0116)\end{array}$ & & $\begin{array}{l}-0.00588^{*} \\
(0.00347)\end{array}$ & \\
\hline Deaths & & $\begin{array}{c}-0.0616 * * * \\
(0.00485)\end{array}$ & & $\begin{array}{c}-0.0410 * * * \\
(0.00469)\end{array}$ & & $\begin{array}{c}-0.0605 * * * \\
(0.00469)\end{array}$ & & $\begin{array}{c}-0.0475 * * * \\
(0.0106)\end{array}$ & & $\begin{array}{c}-0.0368 * * * \\
(0.00519)\end{array}$ \\
\hline Stringency Index & $\begin{array}{c}-0.00227^{* * * *} \\
(0.00010)\end{array}$ & $\begin{array}{c}0.00002 \\
(0.00053)\end{array}$ & $\begin{array}{c}-0.00233^{* * *} \\
(0.00010)\end{array}$ & $\begin{array}{l}-0.000495 \\
(0.00042)\end{array}$ & $\begin{array}{c}-0.00221^{* * *} \\
(0.000105)\end{array}$ & $\begin{array}{l}0.000207 \\
(0.00050)\end{array}$ & $\begin{array}{c}-0.00233^{* * *} \\
(0.00024)\end{array}$ & $\begin{array}{l}-0.00111 \\
(0.00109)\end{array}$ & $\begin{array}{c}-0.00245^{* * *} \\
(0.00008)\end{array}$ & $\begin{array}{l}-0.000600 \\
(0.00040)\end{array}$ \\
\hline Infodemic Index & $\begin{array}{c}-0.00112^{* * * *} \\
(0.00012)\end{array}$ & $\begin{array}{c}-0.000388^{* * *} \\
(0.00013)\end{array}$ & $\begin{array}{c}-0.00136 * * * \\
(0.00007)\end{array}$ & $\begin{array}{c}-0.00080^{* * * *} \\
(0.00008)\end{array}$ & $\begin{array}{c}-0.00113^{* * *} \\
(0.00011)\end{array}$ & $\begin{array}{c}-0.000391 * * * \\
(0.00012)\end{array}$ & $\begin{array}{c}-0.00139 * * * \\
(0.00010)\end{array}$ & $\begin{array}{c}-0.000829^{* * *} \\
(0.00011)\end{array}$ & $\begin{array}{c}-0.00137^{* * *} \\
(0.00009)\end{array}$ & $\begin{array}{c}-0.000858^{* * *} \\
(0.00010)\end{array}$ \\
\hline Constant & $\begin{array}{l}0.0190^{* * *} \\
(0.00177)\end{array}$ & $\begin{array}{l}0.0297 * * * \\
(0.00188)\end{array}$ & $\begin{array}{l}0.0462 * \\
(0.0266)\end{array}$ & $\begin{array}{l}0.0547 * * \\
(0.0264)\end{array}$ & $\begin{array}{c}0.0183 * * * \\
(0.00111)\end{array}$ & $\begin{array}{l}0.0289 * * * \\
(0.00105)\end{array}$ & $\begin{array}{l}0.136^{* * * *} \\
(0.00292)\end{array}$ & $\begin{array}{l}0.145^{* * *} \\
(0.00289)\end{array}$ & $\begin{array}{l}0.0108^{* * * *} \\
(0.000835)\end{array}$ & $\begin{array}{c}0.0186^{* * *} \\
(0.00106)\end{array}$ \\
\hline Observations & 2.212 & 1.896 & 2.380 & 2.040 & 2.436 & 2.088 & 672 & 576 & 1.484 & 1.272 \\
\hline Number of Firms & 79 & 79 & 85 & 85 & 87 & 87 & 24 & 24 & 53 & 53 \\
\hline F Test & 0.000 & 0.000 & 0.000 & 0.000 & 0.000 & 0.000 & 0.000 & 0.000 & 0.000 & 0.000 \\
\hline$R$-squared & 0.0916 & 0.0706 & 0.1475 & 0.0918 & 0.089 & 0.071 & 0.131 & 0.087 & 0.182 & 0.100 \\
\hline
\end{tabular}

If a firm pays a dividend at least once, it is included in the "dividend payers" group. Group 1 includes firms that pay dividends once or never in the last five years. Group 2 contains firms that pay dividends two or three times in the last five years. Group 3 includes firms that pay dividends four or five times in the last five years. Daily new cases are divided by the cumulative cases. Daily new deaths are divided by the cumulative deaths. The infodemic index calculates the percentage of all entities (places, companies, etc.) that are somehow linked to COVID-19. Value range between 0 and 100 where a value of 70.00 means that 70 percent of all entities covered by the media are being linked or co-mentioned with COVID-19. The stringency index is based on different government interventions and rescaled to create a score between 0 and 100 (strict=100). The index covers eight policy indicators, school closing, workplace closing, cancellation of public events, restrictions on gathering size, closing public transport, staying at home requirements, restrictions on internal movement, and international travel restrictions. Robust standard errors in parentheses. $* * *$ p $<0.01$, $* * \mathrm{p}<0.05, * \mathrm{p}<0.1$ 


\section{CONCLUSION}

In this research, we try to investigate whether having a high dividend yield has a defending effect on stock prices during the COVID-19 turbulence period. We include 164 manufacturing firms listed in Borsa Istanbul. Firms are ranked as firms with high and low dividend yield according to their last fiveyears' (2015-2019) averages. We reveal that the stock returns of firms with high dividend yield are less affected in the COVID-19 crash. Likewise, firms with a high frequency of dividend payouts are less affected than those who do not. We find similar results under different scenarios. This study may provide guidance for firm owners and policymakers in Turkey. The average dividend yield is very low for Turkish firms. This study exhibits that firms with high dividend yield are regarded as safe havens by investors in this crash caused by COVID-19. Policymakers should encourage shareholders to pay regular dividend payments that will contribute to the stable capital markets in the long-term.

\section{REFERENCES}

Abiad, A., Arao, R. M., Dagli, S., Ferrarini, B., Noy, I., Osewe, P., ... Platitas, R. (2020). The economic impact of the COVID-19 outbreak on developing Asia. Asian Development Bank Briefs, 1-16. https://doi.org/10.22617/BRF200096

Açıkgöz, Ö., \& Günay, A. (2020). The early impact of the Covid-19 pandemic on the global and Turkish economy. Turkish Journal of Medical Sciences, 50(SI-1), 520-526. https://doi.org/10.3906/sag2004-6

Adjaoud, F., \& Ben-Amar, W. (2010). Corporate governance and dividend policy: Shareholders' protection or expropriation? Journal of Business Finance \& Accounting, 37(5-6), 648-667. https://doi.org/10.1111/j.1468-5957.2010.02192.x

Ahmad, T., Haroon, H., Baig, M., \& Hui, J. (2020). Coronavirus disease 2019 (COVID-19) Pandemic and economic Impact. Pakistan Journal of Medical Sciences, 36(COVID19-S4). https://doi.org/10.12669/pjms.36.COVID19-S4.2638

Ahmed, H., \& Javid, A. Y. (2008). The determinants of dividend policy in Pakistan (No. 37339).

Al-Awadhi, A. M., Alsaifi, K., Al-Awadhi, A., \& Alhammadi, S. (2020). Death and contagious infectious diseases: Impact of the COVID-19 virus on stock market returns. Journal of Behavioral and Experimental Finance, 27, 1-5.

Albulescu, C. T. (2020). COVID-19 and the United States financial markets' volatility. Finance Research Letters, (July). https://doi.org/10.1016/j.frl.2020.101699

Ali, M., Alam, N., \& Rizvi, S. A. R. (2020). Coronavirus (COVID-19) - An epidemic or pandemic for financial markets. Journal of Behavioral and Experimental Finance, 27, 1-6. https://doi.org/10.1016/j.jbef.2020.100341 
Yönetim ve Ekonomi Arașttrmalar Dergisi / Journal of Management and Economics Research Cilt/Volume: 19 Sayl/Issue: 2 Haziran/June 2021 ss. /pp. 334-352

Ö. F. Tan, H. Cavlak, Y. Cebeci, N. Güneş Doi: http://dx.doi.org/10.11611/yead.915018

Amankwah-Amoah, J., Khan, Z., \& Wood, G. (2020). COVID-19 and business failures: The paradoxes of experience, scale, and scope for theory and practice. European Management Journal. https://doi.org/10.1016/j.emj.2020.09.002

Ashraf, B. N. (2020a). Economic impact of government interventions during the COVID-19 pandemic: International evidence from financial markets. Journal of Behavioral and Experimental Finance, 27, 1-9. https://doi.org/10.1016/j.jbef.2020.100371

Ashraf, B. N. (2020b). Stock markets' reaction to COVID-19: Cases or fatalities? Research in International Business and Finance, 54, 1-7. https://doi.org/10.1016/j.ribaf.2020.101249

Ashraf, B. N. (2020c). Stock markets' reaction to Covid-19: Moderating role of national culture. Finance Research Letters, 1-20. https://doi.org/10.1016/j.frl.2020.101857

Asquith, P., \& David W. Mullins, J. (1983). The impact of initiating dividend payments on shareholders' wealth. The Journal of Business, 56(1), 77-96.

Assche, A. Van, \& Lundan, S. (2020). From the editor: COVID-19 and international business policy. Journal of International Business Policy, 3, 273-279.

Bahrini, R., \& Filfilan, A. (2020). Impact of novel corunavirus on stock market returns: Evidence form GCC countries. Quantitative Finance and Economics, 4(4), 640-653. https://doi.org/10.1191/146342301682157692

Baig, A. S., Butt, H. A., Haroon, O., \& Rizvi, S. A. R. (2020). Deaths, panic, lockdowns and US equity markets: The case of COVID-19 pandemic. Finance Research Letters, (July). https://doi.org/10.1016/j.frl.2020.101701

Baker, H. K. (2009). Dividends and dividend policy: An overview. In H. K. Baker (Ed.), Dividends and Dividend Policy (pp. 3-20). New Jersey: John Wiley \& Sons Inc.

Baker, H. K., \& Powell, G. E. (1999). How corporate managers view dividend policy. Quarterly Journal of Business and Economics, 38(2), 17-35.

Baker, S. R., Bloom, N., Davis, S. J., Kost, K. K., Sammon, M. C., \& Viratyosin, T. (2020). The Unprecedented Stock Market Impact of COVID-19. NBER Working Paper No. 26945.

Baker, S. R., Bloom, N., Davis, S. J., \& Terry, S. J. (2020). COVID-Induced Economic Uncertainty (NBER Working Paper Series No. NBER Working Paper 26983). Cambridge.

Baldwin, R., \& Mauro, B. W. di (Eds.). (2020). Mitigating the COVID Economic Crisis: Act Fast and Do Whatever It Takes. London: CEPR Press.

Barua, S. (2020). Understanding coronanomics: The economic implications of the coronavirus (COVID19) pandemic. SSRN Electronic Journal. https://doi.org/10.2139/ssrn.3566477 
Black, F., \& Scholes, M. (1974). The effects of dividend yield and dividend policy on common stock prices and returns. Journal of Financial Economics, 1(1), 1-22.

Bradley, M., Capozza, D. R., \& Seguin, P. J. (1998). Dividend policy and cash-flow uncertainty. Real Estate Economics, 26(4), 555-580.

Brodeur, A., Gray, D., Islam, A., \& Bhuiyan, S. J. (2020). A Literature Review of the Economics of COVID-19. Bonn.

Cepoi, C. O. (2020). Asymmetric dependence between stock market returns and news during COVID19 financial turmoil. Finance Research Letters, 36, 1-5. https://doi.org/10.1016/j.frl.2020.101658

Chang, C. L., McAleer, M., \& Wang, Y. A. (2020). Herding behaviour in energy stock markets during the Global Financial Crisis, SARS, and ongoing COVID-19. Renewable and Sustainable Energy Reviews, 134, 1-15. https://doi.org/10.1016/j.rser.2020.110349

Chaudhary, R., Bakhshi, P., \& Gupta, H. (2020). The performance of the Indian stock market during COVID-19. Investment Management and Financial Innovations, 17(3), 133-147. https://doi.org/10.21511/imfi.17(3).2020.11

Chen, M.-H., Demir, E., García-Gómez, C. D., \& Zaremba, A. (2020). The impact of policy responses to COVID-19 on U.S. travel and leisure companies. Annals of Tourism Research Empirical Insights, 1, 1-8. https://doi.org/10.1016/j.annale.2020.100003

Chen, S., Igan, D. O., Pierri, N., Presbitero, A. F., Soledad, M., \& Peria, M. (2020). Tracking the economic impact of COVID-19 and mitigation policies in Europe and the United States. IMF Working Papers, 2020(125)

Chiah, M., \& Zhong, A. (2020). Trading from home: The impact of COVID-19 on trading volume around the world. Finance Research Letters, 37. https://doi.org/10.1016/j.frl.2020.101784

Conlon, T., \& McGee, R. (2020). Safe haven or risky hazard? Bitcoin during the Covid-19 bear market. Finance Research Letters, 35(May). https://doi.org/10.1016/j.frl.2020.101607

Contessi, S., \& Pierangelo, D. P. (2020). The international spread of COVID-19 stock market collapses. Finance Research Letters, (November).

Corbet, S., Goodell, J. W., \& Günay, S. (2020). Co-movements and spillovers of oil and renewable firms under extreme conditions: New evidence from negative WTI prices during COVID-19. Energy Economics, 92, 1-24. https://doi.org/10.1016/j.eneco.2020.104978

Corbet, S., Larkin, C., \& Lucey, B. (2020). The contagion effects of the COVID-19 pandemic: Evidence from gold and cryptocurrencies. Finance Research Letters, 35(March). https://doi.org/10.1016/j.frl.2020.101554 
Yönetim ve Ekonomi Araștırmaları Dergisi / Journal of Management and Economics Research Cilt/Volume: 19 Sayl/Issue: 2 Haziran/June 2021 ss. /pp. 334-352

Ö. F. Tan, H. Cavlak, Y. Cebeci, N. Güneş Doi: http://dx.doi.org/10.11611/yead.915018

Damodaran, A. (2015). Applied Corporate Finance. New York: John Wiley \& Sons, Inc.

Demir, E., Bilgin, M. H., Karabulut, G., \& Doker, A. C. (2020). The relationship between cryptocurrencies and COVID-19 pandemic. Eurasian Economic Review, 10(3), 349-360. https://doi.org/10.1007/s40822-020-00154-1

Demir, E., Simonyan, S., Chen, M. H., \& Marco Lau, C. K. (2020). Asymmetric effects of geopolitical risks on Turkey's tourist arrivals. Journal of Hospitality and Tourism Management, 45, 23-26. https://doi.org/10.1016/j.jhtm.2020.04.006

Denis, D., \& Osobov, I. (2008). Why do firms pay dividends? International evidence on the determinants of dividend policy. Journal of Financial Economics, 89(1), 62-82. https://doi.org/10.1016/j.jfineco.2007.06.006.

Devpura, N., \& Narayan, P. K. (2020). Hourly oil price volatility: The role of COVID-19. Energy Research Letters, 1, 1-5. https://doi.org/10.46557/001c.13683

Dewasiri, N. J., Yatiwelle Koralalage, W. B., Abdul Azeez, A., Jayarathne, P. G. S. A., Kuruppuarachchi, D., \& Weerasinghe, V. A. (2019). Determinants of dividend policy: evidence from an emerging and developing market. Managerial Finance, 45(3), 413-429. https://doi.org/10.1108/MF-09-2017-0331

Espinosa-Méndez, C., \& Arias, J. (2020). COVID-19 effect on herding behaviour in European capital markets. Finance Research Letters. https://doi.org/10.1016/j.frl.2020.101787.

Farrukh, K., Irshad, S., Shams Khakwani, M., Ishaque, S., Ansari, N. Y., \& McMillan, D. (2017). Impact of dividend policy on shareholders wealth and firm performance in Pakistan. Cogent Business \& Management, 4(1), 1-11. https://doi.org/10.1080/23311975.2017.1408208

Farzami, Y., Gregory-allen, R., Molchanov, A., \& Sehrish, S. (2021). COVID-19 and the liquidty network. Finance Research Letters.

Fendel, R., Neugebauer, F., \& Zimmermann, L. (2021). Reactions of Euro area government yields to Covid-19 related policy measure announcements by the European Commission and the European Central Bank. Finance Research Letters. https://doi.org/10.1016/j.frl.2020.101917

Forti, C. A. B., Peixoto, F. M., \& Alves, D. L. e. (2015). Determinant factors of dividend payments in Brazil. Revista Contabilidade \& Finanças, 26(68), 167-180. https://doi.org/10.1590/1808057x201512260.

Fu, M., \& Shen, H. (2020). COVID-19 and corporate performance in the energy industry. Energy Research Letters, 1(1), 1-5. https://doi.org/10.46557/001c.12967

Gans, J. (2020). Economics in the Age of COVID-19. London: The MIT Press. 
Yönetim ve Ekonomi Arașttrmalar Dergisi / Journal of Management and Economics Research Cilt/Volume: 19 Sayl/Issue: 2 Haziran/June 2021 ss. /pp. 334-352

Ö. F. Tan, H. Cavlak, Y. Cebeci, N. Güneş Doi: http://dx.doi.org/10.11611/yead.915018

Ghosh, S. (2020). Asymmetric impact of COVID-19 induced uncertainty on inbound Chinese tourists in Australia: insights from nonlinear ARDL model. Quantitative Finance and Economics, 4(2), 343-364. https://doi.org/10.3934/qfe.2020016

Goodell, J. W., \& Goutte, S. (2020). Co-movement of COVID-19 and Bitcoin: Evidence from wavelet coherence analysis. Finance Research Letters, 1-6. https://doi.org/10.1016/j.frl.2020.101625

Hale, T., Angrist, N., Cameron-Blake, E., Hallas, L., Kira, B., Majumdar, S., ... Webster, S. (2020). Variation in government responses to COVID-19. BSG Working Paper Series. Blavatnik School of Government. University of Oxford. Retrieved from www.bsg.ox.ac.uk/covidtracker

Harjoto, M. A., Rossi, F., Lee, R., \& Sergi, B. S. (2020). How do equity markets react to COVID-19? Evidence from emerging and developed countries. Journal of Economics and Business, 1-15. Retrieved from https://linkinghub.elsevier.com/retrieve/pii/S0148619520304100

Haroon, O., \& Rizvi, S. A. R. (2020). COVID-19: Media coverage and financial markets behavior-A sectoral inquiry. Journal of Behavioral and Experimental Finance, 27, 1-5. https://doi.org/10.1016/j.jbef.2020.100343

Haruhiko, K. (2020). COVID-19 and the Global Economy: Impact and Challenges - From Asia's Perspective. In 62nd Annual Meeting of the National Association for Business Economics.

Holder, M. E., Langrehr, F. W., \& Hexter, J. L. (1998). Dividend policy determinants: An Investigation of the influences of stakeholder theory. Financial Management, 27(3), 73-82.

Huang, W., \& Zheng, Y. (2020). COVID-19: Structural changes in the relationship between investor sentiment and crude oil futures price. Energy Research Letters, 1, 2-5. https://doi.org/10.46557/001c.13685

Huang, Y., Yang, S., \& Zhu, Q. (2021). Brand equity and the COVID-19 stock market crash: Evidence from U.S. listed firms. Finance Research Letters.

IMF. (2020). World Economic Outlook - Chapter 1: The Great Lockdown. Al-Awadhi, A. M., Alsaifi, K., Al-Awadhi, A., \& Alhammadi, S. (2020). Death and contagious infectious diseases: Impact of the COVID-19 virus on stock market returns. Journal of Behavioral and Experimental Finance, 27, 1-5. https://doi.org/10.1016/j.jbef.2020.100326

Jeris, S. S., \& Nath, R. D. (2020). COVID-19, oil price and UK economic policy uncertainty: Evidence from the ARDL approach. Quantitative Finance and Economics, 4(3), 503-514. https://doi.org/10.3934/qfe.2020023

Kaczmarek, T., Perez, K., Demir, E., \& Zaremba, A. (2021). How to survive a pandemic : The corporate resiliency of travel and leisure companies to the COVID-19 outbreak. Tourism Management, 84, $1-11$. 
Yönetim ve Ekonomi Arașttrmaları Dergisi / Journal of Management and Economics Research Cilt/Volume: 19 Sayl/Issue: 2 Haziran/June 2021 ss. /pp. 334-352

Ö. F. Tan, H. Cavlak, Y. Cebeci, N. Güneş Doi: http://dx.doi.org/10.11611/yead.915018

Kanakriyah, R. (2020). Dividend policy and companies' financial performance. The Journal of Asian $\begin{array}{llll}\text { Finance, } & \text { Economics }\end{array}$ https://doi.org/10.13106/jafeb.2020.vol7.no10.531

Kartal, M. T., Depren, Ö., \& K1lıç-Depren, S. (2020). The determinants of main stock exchange index changes in emerging countries: evidence from Turkey in COVID-19 pandemic age. Quantitative Finance and Economics, 4(4), 526-541. https://doi.org/10.3934/qfe.2020025

Kartal, M. T., K1lı̧̧-Depren, S., \& Depren, Ö. (2020). How main stock exchange indices react to Covid19 pandemic: Daily evidence from East Asian Countries. Global Economic Review, 1-18. https://doi.org/10.1080/1226508X.2020.1869055

Krieger, K., \& Mauck, N. (2020). The impact of the COVID-19 pandemic on dividends. Finance Research Letters. https://doi.org/10.1002/agr.21687

Landry, S. (2020). On the Economic Front. In L. Knorr (Ed.), After the Pandemic - Visions of Life Post Covid-19. Pennsylvania: Sunbury Press, Inc.

Laux, J. A. (2011). Topics in finance, part VII: Dividend policy. SSRN Electronic Journal. https://doi.org/10.2139/ssrn.1885167

M'rabet, R., \& Boujjat, W. (2016). The relationship between dividend payments and firm performance: A study of listed companies In Morocco. European Scientific Journal, 12(4), 469. https://doi.org/10.19044/esj.2016.v12n4p469

Marseguerra, G. (1998). Corporate Financial Decisions and Market Value - Studies on Dividend Policy, Price Volatility, and Ownership Structure. Heidelberg: Physica-Verlag HD. https://doi.org/10.1007/978-3-642-47010-3.

Mazur, M., Dang, M., \& Vega, M. (2020). COVID-19 and the March 2020 stock market crash. Evidence from S\&P1500. Finance Research Letters, (March), 1-8. https://doi.org/10.1016/j.frl.2020.101690

Mazur, M., Dang, M., \& Vo, T. T. A. (2020). Dividend policy and the COVID-19 crisis. SSRN Electronic Journal. https://doi.org/10.2139/ssrn.3723790

McKibbin, W., \& Fernando, R. (2020). The Economic Impact of COVID-19. In R. Baldwin \& B. W. di Mauro (Eds.), Economics in the Time of COVID-19 (pp. 45-52). London: CEPR Press.

McKinsey \& Company. (2020, April). COVID-19: Implications for Business. Our Insights (Executive Briefing).

Mirza, N., Naqvi, B., Rahat, B., \& Rizvi, S. K. A. (2020). Price reaction, volatility timing and funds' performance during Covid-19. Finance Research Letters, 36. https://doi.org/10.1016/j.frl.2020.101657. 
Murekefu, T. M., \& Ouma, O. P. (2012). The relationship between dividend payout and firm performance: A study of listed companies in Kenya. European Scientific Journal, 8(9), 199-215.

Narayan, P. K., Phan, D. H. B., \& Liu, G. (2020). COVID-19 lockdowns, stimulus packages, travel bans, and stock returns. Finance Research Letters. https://doi.org/10.1016/j.frl.2020.101732

OECD. (2020). OECD Interim Economic Assessment - Coronavirus: The world economy at risk.

Okorie, D. I., \& Lin, B. (2020). Stock markets and the COVID-19 fractal contagion effects. Finance Research Letters, (June). https://doi.org/10.1016/j.frl.2020.101640

Panigrahi, S., \& Zainuddin, Y. (2015). Dividend policy decisions: theoretical views and relevant issues. Reports on Economics and Finance, 1, 43-58. https://doi.org/10.12988/ref.2015.596

Prabheesh, K. P., Padhan, R., \& Garg, B. (2020). COVID-19 and the Oil Price - Stock market nexus: Evidence from net oil-importing countries. Energy Research Letters, 1(2), 1-6. https://doi.org/10.46557/001c.13745

Pruitt, S. W., \& Gitman, L. J. (1991). The interactions between the investment, financing, and dividend decisions of major U.S. irms. The Financial Review, 26(3), 409-430. https://doi.org/10.1111/j.1540-6288.1991.tb00388.x

Qian, X., Qiu, S., \& Zhang, G. (2021). The impact of COVID-19 on housing price: Evidence from China. Finance Research Letters. https://doi.org/https://doi.org/10.1016/j.frl.2021.101944

Rababah, A., Al-Haddad, L., Sial, M. S., Chunmei, Z., \& Cherian, J. (2020). Analyzing the effects of COVID-19 pandemic on the financial performance of Chinese listed companies. Journal of Public Affairs, 20(4), 1-6. https://doi.org/10.1002/pa.2440

Ranajee, R., Pathak, R., \& Saxena, A. (2018). To pay or not to pay: what matters the most for dividend payments? International Journal of Managerial Finance, 14(2), 230-244. https://doi.org/10.1108/IJMF-07-2017-0144

Ross, S. A., Westerfield, R. W., \& Jordan, B. D. (2017). Essentials of Corporate Finance. New York: McGraw-Hill Education.

Salisu, A. A., Ebuh, G. U., \& Usman, N. (2020). Revisiting oil-stock nexus during COVID-19 pandemic: Some preliminary results. International Review of Economics and Finance, 69, 280-294. https://doi.org/10.1016/j.iref.2020.06.023

Salisu, A. A., \& Vo, X. V. (2020). Predicting stock returns in the presence of COVID-19 pandemic: The role of health news. International Review of Financial Analysis, 71(June), 1-10. https://doi.org/10.1016/j.irfa.2020.101546

Sergi, B. S., Harjoto, M. A., Rossi, F., \& Lee, R. (2021). Do stock markets love misery? Evidence from 
Yönetim ve Ekonomi Araștırmaları Dergisi / Journal of Management and Economics Research Cilt/Volume: 19 Sayl/Issue: 2 Haziran/June 2021 ss. /pp. 334-352

Ö. F. Tan, H. Cavlak, Y. Cebeci, N. Güneş Doi: http://dx.doi.org/10.11611/yead.915018

the COVID -19. Finance Research Letters.

Sharma, P., Leung, T. Y., Kingshott, R. P. J., Davcik, N. S., \& Cardinali, S. (2020). Managing uncertainty during a global pandemic: An international business perspective. Journal of Business Research, 116, 188-192. https://doi.org/10.1016/j.jbusres.2020.05.026

Szczygielski, J. J., Bwanya, P. R., Charteris, A., \& Brzeszczyński, J. (2021). The only certainty is uncertainty: An analysis of the impact of COVID-19 uncertainty on regional stock markets. Finance Research Letters.

Thorbecke, W. (2020). The impact of the COVID-19 pandemic on the U.S. economy: Evidence from the stock market. Journal of Risk and Financial Management, 13(10), 1-32. https://doi.org/10.3390/jrfm13100233

Topcu, M., \& Gulal, O. S. (2020). The impact of COVID-19 on emerging stock markets. Finance Research Letters, 36, 101691. https://doi.org/10.1016/j.frl.2020.101691

United Nations. (2020). Impact of the COVID-19 Pandemic on Trade and Development. New York: United Nations Publications.

Watson, D., \& Head, A. (2016). Corporate Finance: Principles and Practice. Harlow: Pearson Education Ltd.

World Bank. (2021). Global Economic Prospects, January 2021. Washington: The World Bank. https://doi.org/10.1596/978-1-4648-1612-3

Wu, D. D., \& Olson, D. L. (2020). Introduction. In Pandemic Risk Management in Operations and Finance - Modeling the Impact of COVID-19 (pp. 1-5). Cham: Springer Nature Switzerland AG. https://doi.org/10.1007/978-3-030-52197-4_1

Yarovaya, L., Mirza, N., Abaidi, J., \& Hasnaoui, A. (2021). Human capital efficiency and equity funds' performance during the COVID-19 pandemic. International Review of Economics and Finance, 71, 584-591. https://doi.org/10.1016/j.iref.2020.09.017

Yi, X., Bai, C., Lyu, S., \& Dai, L. (2021). The impacts of the COVID-19 pandemic on China's green bond market. Finance Research Letters.

Yilmazkuday, H. (2020). Coronavirus Disease 2019 and the Global Economy. SSRN Electronic Journal. https://doi.org/10.5853/jos.2020.01760

Zaremba, A., Aharon, D. Y., Demir, E., Kizys, R., \& Zawadka, D. (2021). COVID-19, government policy responses, and stock market liquidity around the World. Research in International Business and Finance, 56, 1-9. https://doi.org/10.2139/ssrn.3631177

Zaremba, A., Kizys, R., Aharon, D. Y., \& Demir, E. (2020). Infected markets: Novel coronavirus, 
government interventions, and stock return volatility around the globe. Finance Research Letters,

35. https://doi.org/10.1016/j.frl.2020.101597

\begin{tabular}{|c|c|c|}
\hline $\begin{array}{c}\text { KATKI ORANI / } \\
\text { CONTRIBUTION RATE }\end{array}$ & $\begin{array}{l}\text { AÇIKLAMA / } \\
\text { EXPLANATION }\end{array}$ & $\begin{array}{c}\text { KATKIDA BULUNANLAR / } \\
\text { CONTRIBUTORS }\end{array}$ \\
\hline $\begin{array}{c}\text { Fikir veya Kavram / Idea } \\
\text { or Notion }\end{array}$ & $\begin{array}{c}\text { Araştırma hipotezini veya } \\
\text { fikrini oluşturmak / Form } \\
\text { the research hypothesis or } \\
\text { idea }\end{array}$ & $\begin{array}{r}\text { Res. Asst. Ömer Faruk TAN } \\
\text { (Ph.D.) } \\
\text { Res. Asst. Hakan CAVLAK } \\
\text { (Ph.D.) } \\
\text { Res. Asst. Yasin CEBECİ (Ph.D.) } \\
\text { Res. Asst. Necati GÜNEŞ }\end{array}$ \\
\hline Tasarım / Design & $\begin{array}{l}\text { Yöntemi, ölçeği ve deseni } \\
\text { tasarlamak / Designing } \\
\text { method, scale and pattern }\end{array}$ & $\begin{array}{r}\text { Res. Asst. Ömer Faruk TAN } \\
\text { (Ph.D.) } \\
\text { Res. Asst. Hakan CAVLAK } \\
\text { (Ph.D.) } \\
\text { Res. Asst. Yasin CEBECİ (Ph.D.) } \\
\text { Res. Asst. Necati GÜNEŞ }\end{array}$ \\
\hline $\begin{array}{c}\text { Veri Toplama ve İşleme / } \\
\text { Data Collecting and } \\
\text { Processing }\end{array}$ & $\begin{array}{l}\text { Verileri toplamak, } \\
\text { düzenlenmek ve raporlamak } \\
\text { / Collecting, organizing and } \\
\text { reporting data }\end{array}$ & $\begin{array}{r}\text { Res. Asst. Ömer Faruk TAN } \\
\text { (Ph.D.) } \\
\text { Res. Asst. Hakan CAVLAK } \\
\text { (Ph.D.) } \\
\text { Res. Asst. Yasin CEBECİ (Ph.D.) } \\
\text { Res. Asst. Necati GÜNEŞ }\end{array}$ \\
\hline $\begin{array}{l}\text { Tartışma ve Yorum / } \\
\text { Discussion and } \\
\text { Interpretation }\end{array}$ & $\begin{array}{c}\text { Bulguların } \\
\text { değerlendirilmesinde ve } \\
\text { sonuçlandırılmasında } \\
\text { sorumluluk almak / Taking } \\
\text { responsibility in evaluating } \\
\text { and finalizing the findings }\end{array}$ & $\begin{array}{r}\text { Res. Asst. Ömer Faruk TAN } \\
\text { (Ph.D.) } \\
\text { Res. Asst. Hakan CAVLAK } \\
\text { (Ph.D.) } \\
\text { Res. Asst. Yasin CEBECİ (Ph.D.) } \\
\text { Res. Asst. Necati GÜNEŞ }\end{array}$ \\
\hline $\begin{array}{l}\text { Literatür Taramas1 / } \\
\text { Literature Review }\end{array}$ & $\begin{array}{c}\text { Çalışma için gerekli } \\
\text { literatürü taramak / Review } \\
\text { the literature required for } \\
\text { the study }\end{array}$ & $\begin{array}{r}\text { Res. Asst. Ömer Faruk TAN } \\
\text { (Ph.D.) } \\
\text { Res. Asst. Hakan CAVLAK } \\
\text { (Ph.D.) } \\
\text { Res. Asst. Yasin CEBECİ (Ph.D.) } \\
\text { Res. Asst. Necati GÜNEŞ }\end{array}$ \\
\hline
\end{tabular}


Hakem Değerlendirmesi: Dış bağımsız.

Çıkar Çatışması: Yazarlar çıkar çatışması bildirmemiştir.

Finansal Destek: Yazarlar bu çalışma için finansal destek almadığını beyan etmiştir.

Teşekkür: -

Peer-review: Externally peer-reviewed.

Conflict of Interest: The authors have no conflict of interest to declare.

Grant Support: The authors declared that this study has received no financial support.

Acknowledgement: We would like to thank Ravenpack for sharing infodemic index data 